\title{
Development of Nerve Conduit using Decellularized Human Umbilical Cord Artery Seeded with Centella asiatica Induced-Neurodifferentiated Human Mesenchymal Stem Cell
}

(Perkembangan Konduit Saraf menggunakan Arteri Tali Pusat Manusia Dinyahsel yang Disemai dengan Centella asiatica Teraruh-Sel Saraf yang Berbeza daripada Sel Stem Mesenkima Manusia)

\author{
HANITA MOHD HUSSIN, RUSZYMAH HAJI IDRUS \\ \& YOGESWARAN LOKANATHAN*
}

\begin{abstract}
Various natural biological conduits have been investigated to bridge peripheral nerve injury especially in critical gap (greater than $3 \mathrm{~cm}$ in human). Autograft, the current gold standard, has several drawbacks including limited availability of donor graft, donor-site morbidity and mismatch in size in clinical practices. The aim of this study was to analyze the development of nerve conduit using decellularized human umbilical cord (HUC) artery seeded with neurodifferentiated human MSCS (ndMSCs) in bridging peripheral nerve gap. Artery conduits obtained from HUC were decellularized to remove native cells $(\mathrm{n}=3)$, then characterized by Hematoxylin and Eosin $(H \& E)$ staining and nuclei counterstaining with DAPI. The decellularized artery conduit was measured for every 2 weeks until 12 weeks. Next, mesenchymal stem cells (MSCs) were differentiated into neural lineage using $400 \mu \mathrm{g} / \mathrm{mL}$ of Centella asiatica. Then, $1.5 \times 10^{6}$ of MSCs or ndMSCs were seeded into decellularized artery conduit to study cell attachment. H\&E staining and nuclei counterstaining with DAPI showed that all cellular components were removed from the HUC arteries. The decellularized artery conduit did not collapse and the lumen remained rigid for 12 weeks. Immunocytochemistry analysis with neural markers namely S100 $\beta$, P75 NGFR, MBP and GFAP showed that MSCs had differentiated into neural lineage cells. H\&E staining showed that the seeded MSCs and ndMSCs attached to the lumen of the conduits as early as 2 days. In conclusion, this study showed that nerve conduit using decellularized HUC artery seeded with neurodifferentiated human MSCS was successfully developed and have the potential to bridge critical nerve gap.
\end{abstract}

Keywords: C. asiatica; mesenchymal stem cells; nerve conduit; nerve injury; umbilical cord artery

\section{ABSTRAK}

Pelbagai konduit biologi semula jadi telah dikaji untuk menyambungkan semula kecederaan saraf periferi terutamanya yang bersaiz kritikal (lebih daripada $3 \mathrm{~cm}$ pada manusia). Rawatan piawai pada masa kini adalah pemindahan autograf, tetapi ia mempunyai beberapa kelemahan dalam amalan klinikal seperti kekurangan tisu penderma, morbiditi pada tapak penderma dan saiz tisu yang tidak sepadan. Tujuan kajian ini dijalankan adalah untuk mengkaji perkembangan konduit saraf menggunakan arteri tali pusat manusia yang telah dinyahsel dan disemai dengan sel saraf yang terbeza daripada sel stem mesenkima. Konduit arteri tali pusat manusia yang telah dinyahsel $(\mathrm{n}=3)$ seterusnya dikaji keberkesanannya menggunakan pewarnaan Hematoxylin dan Eosin $(H \& E)$ dan pewarnaan nukleus oleh DAPI. Konduit arteri itu kemudiannya diukur kepanjangan pada setiap 2 minggu sehingga 12 minggu. Aruhan pembezaan sel saraf daripada sel stem mesenkima telah dilakukan melalui penggunaan $400 \mu \mathrm{g} / \mathrm{mL}$ C. asiatica. Kemudian, $1.5 \times 10^{6} \mathrm{sel}$ stem mesenkima atau sel saraf disemai ke dalam konduit arteri untuk mengkaji perlekatan sel. Pewarnaan Hematoxylin dan Eosin (H\&E) dan DAPI pada nukleus menunjukkan bahawa semua komponen sel telah berjaya dinyahkan daripada arteri tali pusat manusia. Konduit arteri itu tidak menguncup dan lumennya kekal tegar selama 12 minggu. Analisis immunositokimia menggunakan penanda saraf iaitu S100 $\beta$, P75 NGFR, MBP dan GFAP mendedahkan bahawa sel stem mesenkima telah terbeza kepada leluhur sel saraf. Pewarnaan $H \& E$ menunjukkan bahawa sel stem mesenkima dan sel saraf yang telah disemai melekat pada dinding lumen konduit tersebut seawal hari ke-dua. Secara kesimpulannya, kajian ini menunjukkan bahawa konduit saraf menggunakan arteri tali pusat manusia dan disemai dengan sel saraf yang terbeza daripada sel stem mesenkima telah berjaya dihasilkan dan berpotensi untuk diimplan pada kecederaan saraf periferi bersaiz kritikal.

Kata kunci: Arteri tali pusat; C. asiatica; kecederaan saraf; konduit saraf; sel stem mesenkima 


\section{INTRODUCTION}

Insufficient functional restoration associated with peripheral nerve injury (PNI) has been a significant critical issue which sometime resulted to permanent disability. It was estimated that 50000 procedures were performed annually to repair damaged peripheral nerves at the cost of USD 7 billion per year (Liao et al. 2013). Despite rapid clinical advancement, the treatment of PNI is still a challenge especially in critical gap (greater than $3 \mathrm{~cm}$ ) (Kaizawa et al. 2017; Liao et al. 2013). This condition is worsened by the limited regeneration of peripheral nerve that depends on several factors including the length of injury, presence of neurotrophic factors and Schwann cells (Höke 2006). The current gold standard procedure to bridge critical gap of PNI is the use of autologous nerve grafts, where the sural nerve is the most commonly used autograft (Ray et al. 2010). Albeit its success in nerve regeneration and restoration of functional recovery is well documented, nerve autografting has several drawbacks including limited availability of donor graft, mismatch in size in clinical practice, additional surgery trauma at donor sites and associated functional loss of donor nerve (Gordon et al. 2003; Zhan et al. 2013).

In the attempt to avoid the shortcomings of nerve autograft, researchers have focus their attention to the development of nerve conduits. Food and Drug Administration (FDA), has approved several nerve conduits made of natural polymers, NeuraGen, NeuroFlex, NeuroMatrix (Type 1 Collagen) and synthetic polymers, Neurotube (PGA) and Neurolac (caprolactone) (Deal et al. 2012; Kehoe et al. 2012). A study reported that collagen coated PLGA nerve conduit seeded with neural differentiated mesenchymal stem cells is suitable for use as artificial nerve conduit (Hidayah et al. 2012; Sulong et al. 2014). However, several disadvantages accompanying with synthetic nerve conduits have hindered its optimal functional recovery including chronic inflammation, acidic degradation by-product and rigidity mismatch (Deal et al. 2012; Liao et al. 2013).

As an alternative, studies have been made on the use of natural biological nerve conduits for example vein, artery and fibroblast-made scaffold. The use of vein graft has shown effective results to treat nerve damage and enhance functional recovery in in vivo study (Hassan et al. 2012; Lokanathan et al. 2014). However, several problems related with unmodified veins including; easily collapse and the presence of valves found to block axonal regeneration (Crouzier et al. 2009). On the other hand, the use of arterial graft seems to be gaining attention because of the few adding advantages, such as wall thickness, permeability and mechanical rigidity. Earlier study reported that artery conduit seeded with mesenchymal stem cells enhanced significantly axonal regeneration and prevented muscular atrophy (Liao et al. 2013). Sun et al. (2011) reported that the use of decellularized artery conduit seeded with differentiated adipose derive stem cell resulted in better nerve regeneration and functional recovery. Apparently, human umbilical cord (HUC) artery might represent a good source as a nerve conduit as it is easily obtainable, simply isolated and lack branches (Mallis et al. 2014). The HUC collected from health centres were redundant and often disposed as biological samples.

The use of allograft might provoke immunological response and the recipients should be under immunosuppressive drugs for a certain time. This issue can be avoidable by decellularization process, where this process removes native cells, residual blood and other soluble components leaving the extracellular matrix (ECM) that remained intact (Mallis et al. 2014; Quint et al. 2011; Tuan-Mu et al. 2014). Besides, decellularized blood vessels maintained their three dimensional structure and reduce immunogenicity (Rodríguez-Rodríguez et al. 2017). Furthermore, decellularized materials can be seeded with various cells and supplied with growth factors to mimic native tissue and consequently generate functional tissue (Gui et al. 2009).

On the other hand, the medicinal use of Centella asiatica (L.) or is also known as pegaga in Malaysia, Brahmi in Unani medicines, Mandookaparni in Ayurveda, Gotu Kola or Indian Pennywort in the western world (Jamil et al. 2007), has been long documented in the previous studies. An accumulating evidence has demonstrated that this herbal medicine has neuroprotective and neuroregenerative properties (Lokanathan et al. 2016; Omar et al. 2011). A study found that the bioactive compound present in C. asiatica fresh leaf juice has neuronal dendritic growth stimulating property, which act as neuronal basis for enhancing learning and memory (Mohandas et al. 2009). Another study showed that the treatment of $C$. asiatica ethanolic extract in rats demonstrated more rapid functional recovery and increased axonal regeneration, indicating that the axons grew at a faster rate, pointed out its neuroregenerative properties (Soumyanath et al. 2005). These remedial values were believed to have been largely contributed by its bioactive components namely asiatic acid, madecassic acid, asiaticoside and madecassoside (Puttarak et al. 2016).

The beneficial use of $C$. asiatica is not limited to just neural properties, this plant has several other advantages including on wound healing of skin, oxidative stress, anti-inflammatory, anti-depressant, sedative, gastric ulcer, memory-enhancing, anti-diabetic, cardioprotective, hepatoprotective and immunomodulation (Nurlaily et al. 2012; Ruszymah et al. 2012; Said 2009; Somboonwong et al. 2012; Tiwari et al. 2011). Despite its good values, $C$. asiatica however exert some negative effects in terms of antifertility in male mice and anti-proliferative activities on cells (Mohd Heikal et al. 2014; Noor et al. 2004). Thus, it is important to determine the optimal concentration of C. asiatica in order to gain its fully benefit.

Our in vitro study has confirmed that minimal dose of $C$. asiatica $(400 \mu \mathrm{g} / \mathrm{mL})$ has the capacity to differentiate human Wharton's Jelly mesenchymal stem 
cells into Schwann cells or other neural lineage cells (Norazzila et al. 2018, 2017). Thus, the focus of this study was to develop decellularized human umbilical cord artery seeded with $400 \mu \mathrm{g} / \mathrm{mL} C$. asiatica induced - neurodifferentiated human MSCs (ndMSCs) as an alternative nerve conduit for peripheral nerve injury.

\section{MATERIALS AND METHODS}

\section{DECELLULARIZATION OF THE HUMAN UMBILICAL CORD ARTERY}

This study was conducted at Universiti Kebangsaan Malaysia Medical Centre, Malaysia. All samples were collected with informed consent from patients and approved by Research Ethics Committee of Universiti Kebangsaan Malaysia (UKM) (no. FF-2017-175). Human umbilical cord (HUC) samples $(n=3)$ were obtained from healthy patients undergoing full term elective caesarean delivery. After collection, the HUC were rinsed several times with sterile Dulbecco's phosphate buffer saline (DPBS) (Sigma Aldrich, USA) to wash any bloodstains. The HUC samples were dissected and stripped off the arteries and vein. The Wharton's jelly part was kept for mesenchymal stem cells isolation. The decellularization process of the HUC arteries was done based on previously published protocol (Sun et al. 2011). After cleaning them off blood and connective tissue, the arteries were rinsed in sterile ice-cold saline. Then, they were decellularized with $0.025 \%$ trypsin-ethylenediaminetetraacetic acid (EDTA) (Sigma Aldrich, USA) in DPBS for $1 \mathrm{~h}$, deionized distilled water (ddH2O) for $2 \mathrm{~h}, 1 \%$ detergent Triton X-100 (Sigma Aldrich, USA) in DPBS for $4 \mathrm{~h}$, ddH2O for $1 \mathrm{~h}$ and $1 \%$ sodium dodecyl sulfate (SDS) (Sigma Aldrich, USA) in DPBS for $4 \mathrm{~h}$. All procedures were performed under sterile conditions with continuous shaking at $37^{\circ} \mathrm{C}$. The decellularized HUC arteries were then sterilized with $70 \%$ alcohol (SYSTERM, Malaysia) $(3 \times 15$ min each), cut approximately $2 \mathrm{~cm}$ each and analysed using Hematoxylin \& Eosin (H\&E) (Richard-Allan Scientific, USA) staining and nuclei counter-staining with DAPI (Invitrogen, USA).

\section{HEMATOXYLIN AND EOSIN (H\&E) STAINING AND NUCLEI COUNTER-STAINING WITH DAPI (4',6-DIAMIDINO-2- PHENYLINDOLE) OF THE DECELLULARIZED HUC ARTERY}

The decellularized and native arteries (control) were fixed with $10 \%$ formalin (Leica Biosystems, USA) for $24 \mathrm{~h}$. The arteries were then rinsed with DPBS and processed using a series of chemicals, $50 \%$ and $70 \%$ alcohol (MERCK, Germany) (1 h each), 95\% alcohol (1.5 h), absolute alcohol $(3 \times 1 \mathrm{~h}, 1.5 \mathrm{~h}$ and $1.5 \mathrm{~h})$, equal part alcohol:toluene $(1.5$ $\mathrm{h})$, toluene $(3 \times 1 \mathrm{~h}, 1.5 \mathrm{~h}$ and $1.5 \mathrm{~h})$ and paraffin wax (2 $\times 2 \mathrm{~h}$ each). Then, tissues were embedded using paraffin wax for histological analysis. Tissue sections of 2-5 $\mu \mathrm{m}$ thin were cut using a microtome (Leica, Germany). The tissue sections were then dewaxed and dehydrated with a series of chemicals; xylene (J.T. Baker, USA) $(3 \times 5 \mathrm{~min}$ each) and alcohol (100\%, 95\% and 70\%) (3 min each) followed by Hematoxylin staining (10 $\mathrm{min})$ and Eosin staining (4 min). Lastly, the tissue sections were rehydrated with alcohol (95\% and 100\%) (3 min each) and xylene (3 $\times 5$ min each). The tissue sections were mounted using mounting solution and observed under light microscope (OLYMPUS, CH30). For nuclei counterstaining with DAPI, after dehydration, tissue sections were permeabilized with $0.5 \%$ Triton X-100 for $20 \mathrm{~min}$ and incubated with DAPI $(1 / 15000)$ for $40 \mathrm{~min}$ in the dark at room temperature. Next, tissues sections were mounted and observed under fluorescence microscope (Nikon, ECLIPSE Tỉ).

\section{MEASUREMENT OF LENGTH OF DECELLULARIZED HUC ARTERY}

$1.5 \mathrm{~cm}$ of HUC arteries conduit was put in low-glucose Dulbecco's modified Eagle medium (DMEM-LG) (Gibco, USA) complete medium (containing $10 \%$ fetal bovine serum (FBS) (Gibco, USA), 1\% Glutamax (Gibco, USA) and $1 \%$ antibiotic-antimycotic (Gibco, USA) at $37^{\circ} \mathrm{C}$ in humidified 5\% $\mathrm{CO}_{2}$ incubator (New Brunswick Galaxy® 170 Series, Eppendorf, USA) and the length was measured up every 2 weeks until 12 weeks.

\section{ISOLATION AND PROPAGATION OF HUMAN WHARTON'S} JELLY MESENCHYMAL STEM CELLS (hWJMSCs)

The human Wharton's Jelly samples were processed within $3 \mathrm{~h}$ of collection as prescribed in the previous study (Lim et al.2016). The Wharton's Jelly was minced and digested with $0.6 \%$ Collagenase Type 1 (Worthington, USA) in incubator shaker $(250 \mathrm{rpm})$ at $37^{\circ} \mathrm{C}$ for $2 \mathrm{~h}$. After complete digestion, the digested tissue was centrifuged at $5000 \mathrm{rpm}$ for $5 \mathrm{~min}$ to obtain cell pellet. The cell pellet was washed with DPBS and subjected for another centrifugation. Then, the cell pellet was resuspended in DMEM-LG complete medium and cultured in T-25 $\mathrm{cm}^{2}$ culture flask (Corning, USA) at $37^{\circ} \mathrm{C}$ in humidified $5 \% \mathrm{CO}_{2}$ incubator for expansion. Culture medium was changed every 3 days. Once it reached $80 \%$ confluency, it was detached using $0.05 \%$ trypsin and expanded into new flasks at a density of $5 \times 10^{3}$ cells $/ \mathrm{cm}^{2}$. To ensure the consistency, passage 3 cells were used throughout the experiment.

\section{NEURODIFFERENTIATION OF MSCS USING $400 \mathrm{MG} / \mathrm{ML}$ C. ASIATICA}

The differentiation of hWJMSCs into neural lineage was performed using $C$. asiatica in the concentration of 400 $\mu \mathrm{g} / \mathrm{mL}$, as prescribed in the previous study (Norazzila et al. 2018). Before induction, MSCs were seeded at a density of $5 \times 10^{3}$ cells $/ \mathrm{cm}^{2}$ in a 6 well plate (Thermo Scientific, Denmark) and cultured for 2 days for attachment. Then, for the experimental group, the cells were cultured in $\alpha$-MEM LG (Gibco, USA) complete medium supplemented with $400 \mu \mathrm{g} / \mathrm{mL} C$. asiatica. For the negative control group, cells were cultured in $\alpha$-MEM LG complete medium only. Schwann cells purchased from ScienCell, USA and 
cultured in specific Human Schwann Cell Medium (SCM) (ScienCell, USA) served as the positive control group. The cells were treated for 9 days.

\section{IMMUNOCYTOCHEMISTRY (ICC) ANALYSIS OF NEURODIFFERENTIATED MSCs (ndMSCs)}

The ndMSCs was evaluated based on the expression of neural markers using ICC analysis. The markers investigated are calcium-binding protein B (S100 $\beta)$, p75 nerve growth factor receptor (p75 NGFR), myelin basic protein (MBP) and glial fibrillary acidic protein (GFAP). After 9 days of treatment, all cells were washed with DPBS and fixed with $4 \%$ paraformaldehyde (PFA) (Sigma Aldrich, USA) for $24 \mathrm{~h}$. The next day, cells were washed with DPBS (3 $\times 5$ min each) and permeabilized with $0.5 \%$ Triton X-100 for $20 \mathrm{~min}$. Cells were then washed with washing solution, $0.1 \%$ Tween 20 (Sigma Aldrich, USA) $(3 \times 5$ min each) and blocked with $10 \%$ goat serum (Gibco, New Zealand) for $1 \mathrm{~h}$ at $37^{\circ} \mathrm{C}$. Next, cells were incubated overnight at $4^{\circ} \mathrm{C}$ with the following primary antibodies: mouse monoclonal anti-S100 $\beta$ (1/1000) (Abcam, UK), rabbit polyclonal antiNGF 75 receptor (1/500) (Abcam, UK), mouse monoclonal anti-MBP (1/1000) (Thermo Fisher Scientific, USA) and mouse monoclonal anti-GFAP $(2.5 \mu \mathrm{g} / \mathrm{mL})$ (STEMCELL Technologies, Canada). On the next day, cells were washed with washing solution, $0.1 \%$ Tween $20(3 \times 5$ min each $)$ and incubated with the secondary antibody, Goat AntiMouse IgG (Texas Red) (1/300) (Abcam, UK) or Goat Anti-Rabbit IgG (FITC) (1/300) (Abcam, UK), at $37^{\circ} \mathrm{C}$ for $2 \mathrm{~h}$. Nuclei were counter-stained with DAPI for $40 \mathrm{~min}$ in the dark at room temperature. Cells were examined under fluorescence microscope.

\section{SEEDING OF MSCS AND NDMSCS INTO DECELLULARIZED HUC ARTERY CONDUIT}

Arteries were cut approximately $1.5 \mathrm{~cm}$ each and MSCs or ndMSCs were seeded into the conduit. Briefly, the cell pellet containing $1.5 \times 10^{6}$ of MSCs or ndMSCs were resuspended in $20 \mu \mathrm{L}$ of FBS and seeded directly into the lumen of the conduit using p200 micropipette (Eppendorf, Germany). The MSCs seeded conduit (MC) or ndMSCs seeded conduit (NC) were then cultured for another 2 days at $37^{\circ} \mathrm{C}$ in humidified $5 \% \mathrm{CO}_{2}$ incubator to enable cell attachment before conduit implantation.

\section{H\&E STAINING OF MSCS SEEDED CONDUIT (MC) AND NDMSCS SEEDED CONDUIT (NC) (PRE-GRAFTING)}

After seeding, H\&E staining was done to evaluate the MC and NC histological structure before implantation. After 2 days in incubation, the MC or NC was first fixed with $10 \%$ formalin for $24 \mathrm{~h}$. The protocol for H\&E staining was used as previously discussed.

\section{RESULTS AND DISCUSSION}

The efficiency of decellularization process of the human umbilical cord (HUC) arteries and cell seeding attachment play a vital role in developing nerve conduit. This study was performed to analyze the development of nerve conduit using decellularized human umbilical cord (HUC) artery seeded with neurodifferentiated human MSCs (ndMSCs) in bridging peripheral nerve gap. To investigate the effectiveness of a developed nerve conduit, $H \& E$ staining, nuclei counterstaining with DAPI, measurement of the length of artery conduit and in vitro evaluation of constructed nerve conduit were performed.

\section{DECELLULARIZATION AND DEVELOPMENT OF THE HUC ARTERY}

Freshly isolated HUC were dissected to collect arteries inside (Figure 1(A)) and directly cleaned from blood and connective tissue (Figure 1(B)). After various stages of processing, the decellularized HUC arteries did not collapse and the lumen remained rigid (Figure 1(C)). This could be due to the extracellular matrix (ECM) of the HUC arteries were retained during the decellularization process. There were two arteries reside within HUC while there was only one vein. The HUC arteries have thicker muscular wall compared to HUC veins and it did not have branches. The decellularization process removed all cellular and nuclei material. In this study, the HUC arteries were decellularized with a combination of enzymatic and detergent as it improved decellularization efficiency and retained appropriated extracellular matrix content (Gilpin
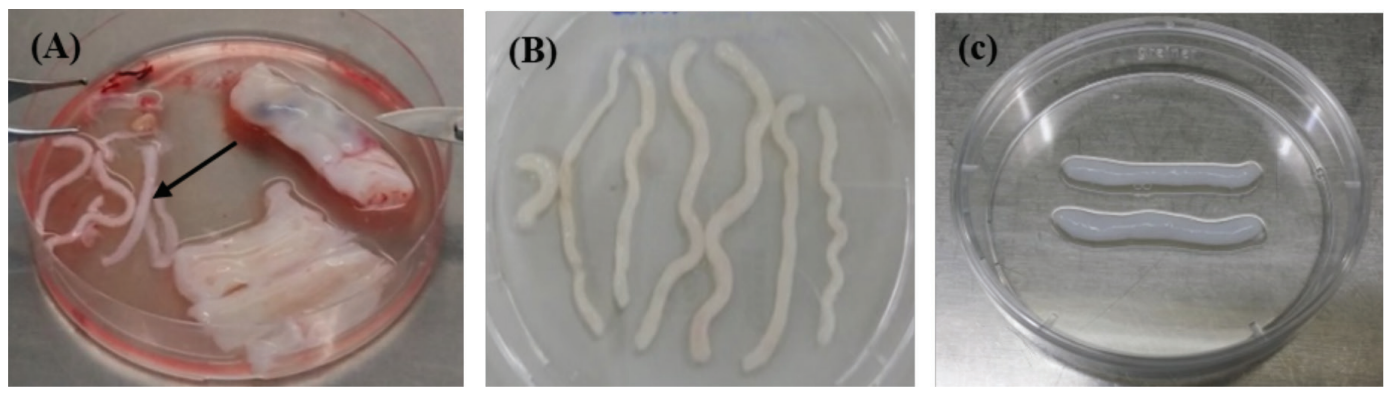

FIGURE 1. Human umbilical cords (HUC) arteries after various stages of processing (A) HUC after dissecting to collect arteries inside. Arrow shows the HUC arteries (B) HUC arteries after cleaning of blood and connective tissue and (C) Decellularized artery conduit 
et al. 2017). The HUC arteries have a uniform diameter of $1.5 \mathrm{~mm}$ under collapsed conditions and 4.5-5.5 mm under physiological pressure as stated in aforementioned study (Gui et al. 2009). Similarly with this study, the HUC arteries has unique criteria of long graft without branches and has similar dimensions with peripheral nerve (Tuan$\mathrm{Mu}$ et al. 2014). Besides, HUC was not frozen before decellularization as a study reported that the efficiency of decellularization were reduced when frozen HUC were used (Tuan-Mu et al. 2014).

\section{HEMATOXYLIN \& EOSIN (H\&E) STAINING AND NUCLEI COUNTER STAINING WITH DAPI OF DECELLULARIZED HUC ARTERY CONDUIT}

The HUC arteries decellularization efficiency was evaluated by staining of the nuclear and cellular components. H\&E staining was done to compare the existence of cellular components between the native artery (Figure $2(\mathrm{~A}) \&$ 2(C)) and decellularized artery (Figure 2(B) \& 2(D)). H\&E staining showed the cellular components did not exist in decellularized artery as compared to native artery. Nuclei counterstaining with DAPI added another prove that nuclear material was absence after decellularization (Figure 2(F)) as compared to native artery (Figure 2(E)). After various stages of processing and decellularizing for $12 \mathrm{~h}$, the cellular and nuclear material was completely removed and non-detectable in the vessel wall. This indicated the removal of smooth muscle cells and endothelial cells (native cell) from the vessel wall of the HUC artery. The extracellular matrix and basement membrane of the decellularized artery on the other hand remained intact and preserved (Figure 2(B), 2(D) \& 2 (F)).

Previous study stated that the decellularization process that used SDS solution was effective in reducing cellular content. The decellularization process removed immunogenic cells, other soluble components of the matrix and enhanced permeability (Crouzier et al . 2009). Another study reported that the extra cellular matrix of collagen fibers was well preserved of a decellularized HUC artery. The decellularized HUC artery minimized immunogenicity, supported cell seeding and could be stored for a long term (Gui et al. 2009). In addition, decellularized HUC artery lacking of cellular and nuclear residues thus make it suitable for developing nerve graft (Mallis et al. 2014). Based on the results of H\&E staining and nuclei counterstaining with DAPI in this study, it is concluded that by decellularization process, all residual blood, cells and other soluble components have been successfully removed. This technique is important to prevent any rejection during subsequent implantation in clinical use.
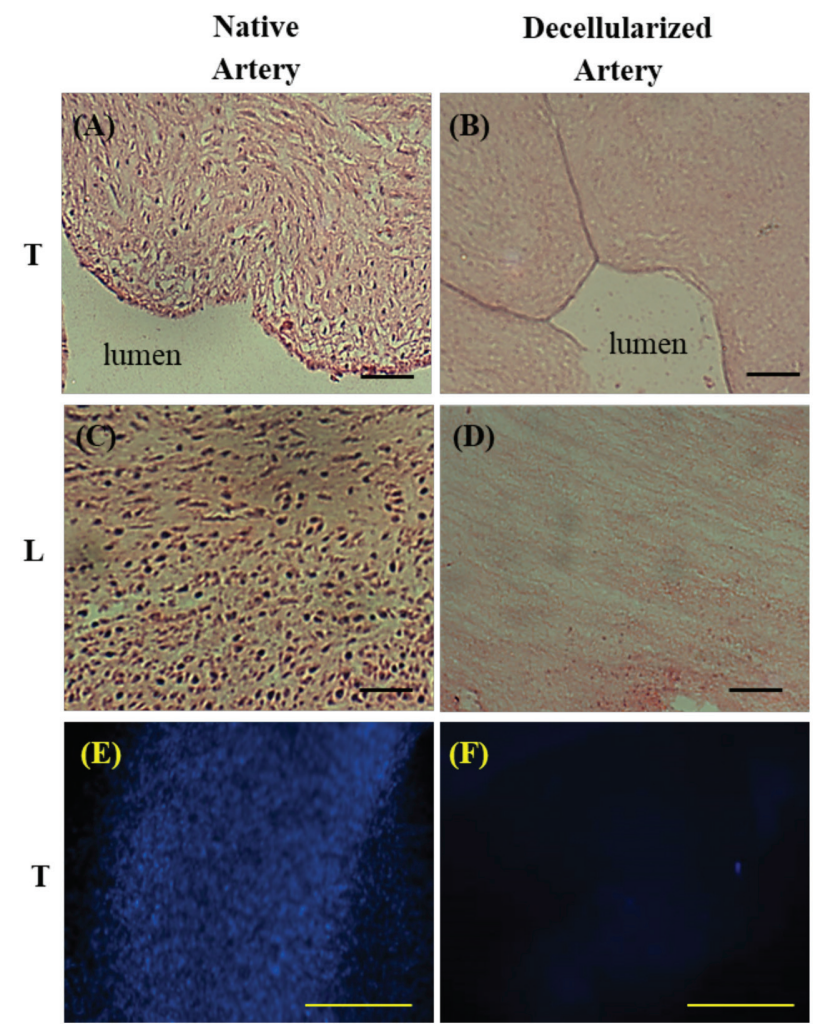

FIGURE 2. H\&E staining and nuclei counterstaining with DAPI of the native artery (control) and decellularized artery. (A, B , C, D) H\&E staining of arteries, (E, F) nuclei counterstaining with DAPI of the arteries. H\&E staining showed no cellular components were detectable in decellularized artery $(\mathrm{B}, \mathrm{D})$ compared to native artery $(\mathrm{A}, \mathrm{C})$. Nuclei counterstaining with DAPI demonstrated that the nuclear materials were removed in decellularized artery $(\mathrm{F})$ compared to native artery

(E). $\mathrm{T}=$ transverse section, $\mathrm{L}=$ longitudinal section. Magnification, $10 \times$ Scale bar, $100 \mu \mathrm{m}$ 


\section{MEASUREMENT OF LENGTH OF DECELLULARIZED HUC ARTERY CONDUIT}

After 12 weeks in incubation, the decellularized HUC artery conduit did not degrade and swell. The decellularized HUC artery conduit also did not collapse and the length remained almost the same throughout the whole study. Only a small change $(11.8 \% \pm 1.85)$ was recorded and it is negligible (Figure 3). Furthermore, the decellularized HUC artery conduit maintained its shape and three-dimensional properties. The maintaining of the length and shape of the decellularized HUC artery conduit could be due to preserved ECM during decellularization process and the thick muscular wall of the artery vessels. Thick muscular wall of the arteries could prevent degradation and muscular infiltration during clinical implantation in the nerve area. A few studies have accumulated the evidence of the good biomechanical strength of decellularized arteries. Consistent with our findings, a study mentioned that decellularized arteries or blood vessels maintained their three dimensional properties (Rodríguez-Rodríguez et al. 2017). Besides, their biomechanical strength is better that synthetic materials in both in vitro and in vivo models (Schaner et al.2004). Another investigation demonstrated that decellularization of arteries modified structural and elastic properties of the vessels, however the wall thickness remained the same. To compare with native arteries, decellularized arteries were larger, thinner and stiffer which able to accommodate high pressure before rupturing (Roy et al. 2005). To point out an ideal nerve conduit, certain criteria need to be fulfilled; sufficient mechanical strength, not easily collapse and presence of tubular lumen for nerve cells to grow.

\section{ISOLATION AND PROPAGATION OF HUMAN WHARTON'S JELLY MSCS (hWJMSCs)}

hWJMSCs were successfully isolated using enzymatic digestion from the human umbilical cord sample. The mesenchymal stem cells isolated displayed homogenous, plastic adherence and bipolar spindle shaped morphology in monolayer cultures. In the early passage, the cells demonstrated more fibroblastic like appearance and spindle shaped morphology. Towards later passage, the cells were more enlarged and flattened (Figure 4). This could be due to long term in vitro expansion that contributes to cell maturing and aging (Neuhuber et al. 2008; Safwani et al. 2012; Zhuang et al. 2015). The use of hWJMSCs is said to be a desirable choice compared to other sources of mesenchymal stem cells such as bone marrow or peripheral blood because it is easily available and not a major ethical concern.

According to previous study done, these cells possess unique characteristics of both human mesenchymal stem cells and human embryonic stem cells (ESC) based on immunophenotyping analysis. On the other hand, these cells lacked hematopoietic markers. Furthermore, these cells were able to differentiate into trilineage differentiation which is osteogenic, adipogenic and chondrogenic (Lim et al. 2016). The mentioned criteria, spindle shaped morphology, plastic adherence, express mesenchymal stem cells markers, lacked hematopoietic markers and capability of trilineage differentiation are the minimum criteria for mesenchymal stem cells (Dominici et al. 2006). Since similar isolation protocol and laboratory environment were being used in this experiment, it is assumed that mesenchymal stem cells isolated in this study possess the same characteristics.

\section{IMMUNOCYTOCHEMISTRY (ICC) ANALYSIS OF NEURODIFFERENTIATED MESENCHYMAL STEM CELLS (ndMSCs)}

The capability of mesenchymal stem cells to differentiate into several cells type of mesenchymal origin is well establish. On the other hand, mesenchymal stem cells also have the potential to differentiate into neuroectodermal lineage cells in the presence of neurotrophic factor (Jadalannagari et al. 2015; Wakao et al. 2014). After treated with $400 \mu \mathrm{g} / \mathrm{mL}$ of $C$. asiatica, neurodifferentiated mesenchymal stem cells (ndMSCs) showed the expression of S100 $\beta$, P75 NGFR, MBP and GFAP markers in a similar manner with Schwann cells. As opposed to mesenchymal
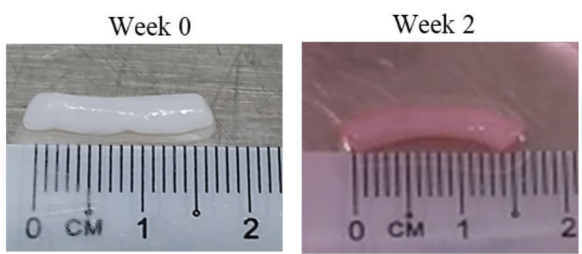

Week 8
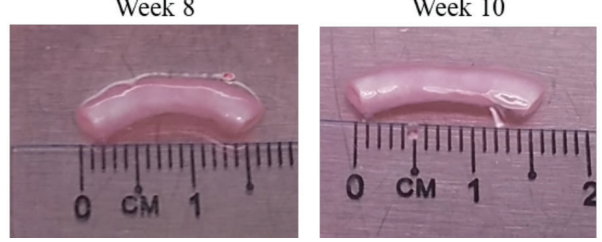

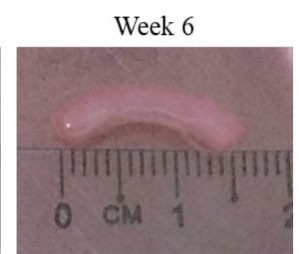

Week 12

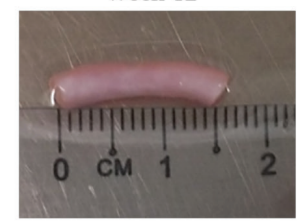

FIGURE 3. The decellularized HUC artery conduit did not degrade and swell after 12 weeks in incubation. A small change $(11.8 \% \pm 1.85)$ was observed on the decellularized HUC artery conduit 
P0

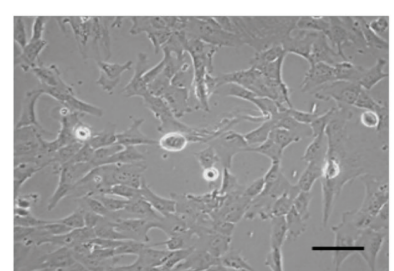

P1

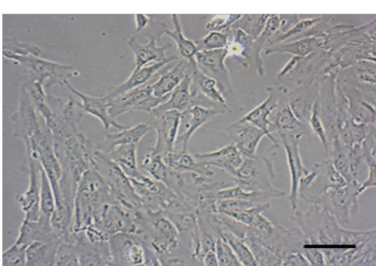

P2

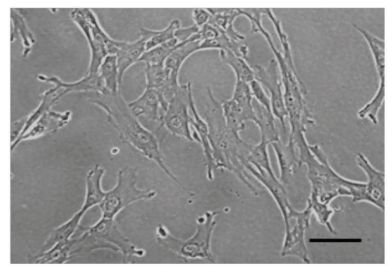

P4

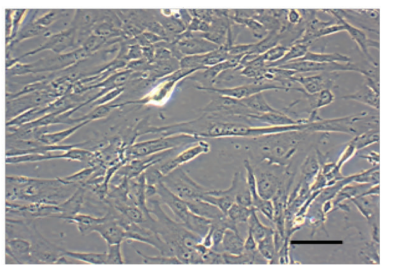

FIGURE 4. Human Wharton's Jelly MSCs from primary culture, passage 0 (P0) until expanded passages, passage 4 (P4), as observed under phase contrast microscope. hWJMSCs demonstrated fibroblastic appearance and spindle shaped morphology in early culture and more flattened shape towards the late passages.

Magnification, $10 \times$ Scale bar, $100 \mu \mathrm{m}$

stem cells, the only expression observed was in S100 $\beta$ marker, while no expression was observed in P75 NGFR, MBP and GFAP markers (Figure 5). The present findings in this study agreed with earlier study stated that minimal concentration of $C$. asiatica $(400 \mu \mathrm{g} / \mathrm{mL})$ has the capacity to differentiate hWJMSCs into Schwann cells or other neural lineage cells (Norazzila et al. 2018).

On the other hand, $\mathrm{S} 100 \beta$ is a calcium-binding protein concentrated in glial cells, however several studies have reported that this Schwann cells specific marker can be expressed by non-neural cells, such as mesenchymal stem cells, as what has been observed in this study (Deng et al. 2006; Michetti et al. 2012). Moreover, a study mentioned that $\mathrm{S} 100 \beta$ marker is not a very reliable marker for Schwann cells because early culture stage of Schwann cells did not express this marker. Similar study also reported that the expression of various Schwann cells related markers at different time point is necessary for the development of Schwann cells (Liu et al. 2015). In addition, the ability of $C$. asiatica to act as a neurotrophic

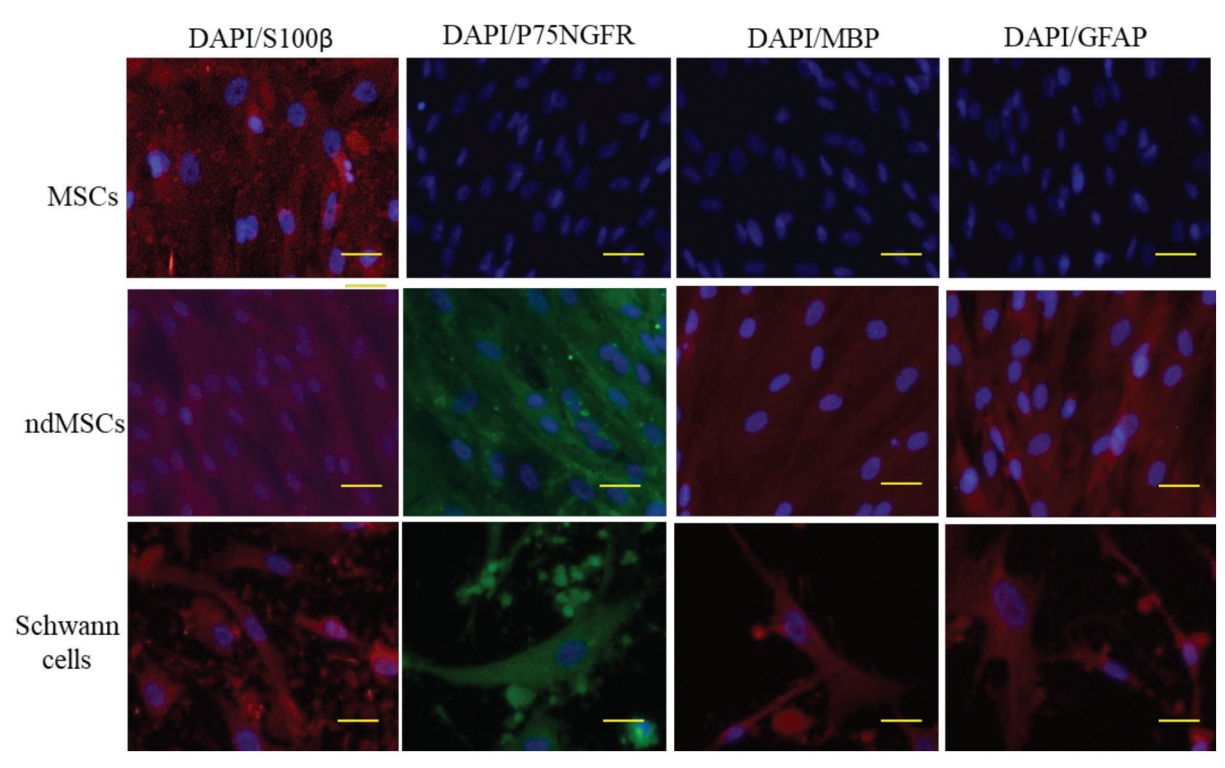

FIGURE 5. Expression of S100 $\beta$, P75 NGFR, MBP and GFAP were observed in the neurodifferentiated MSCs (ndMSCs) in a similar manner as Schwann cells. Meanwhile the expression of S100 $\beta$ was observed in MSCs, however the expression of P75 NGFR, MBP and GFAP were not observed in MSCs. The expressions of neural markers after induction of MSCs showed that MSCs were successfully neurodifferentiated by using $400 \mu \mathrm{g} / \mathrm{mL}$ of $C$. asiatica.

Magnification, $10 \times$ Scale bar, $100 \mu \mathrm{m}$ 
factor and induced the differentiation of mesenchymal stem cells into neural lineage cells might be attributed to the bioactive compounds present; mainly asiatic acid and madecassid asic (Puttarak et al. 2016) that play a major role in the enhancement of neurite outgrowth that happens after differentiation (Jiang et al. 2016; Wanakhachornkrai et al. 2013).

\section{IN VITRO EVALUATION OF CONSTRUCTED NERVE CONDUIT (PRE-GRAFTING)}

An ideal nerve conduit should support recellularization because the seeding of the cells into nerve conduit has been shown to be essential in promoting nerve regeneration (Kaizawa et al. 2017, 2016; Shalaby et al. 2017; Xu et al. 2016). To test whether decellularized HUC artery conduit support recellularization, mesenchymal stem cells and neurodifferentiated mesenchymal stem cells (ndMSCs) were seeded into the luminal surface of the decellularized HUC artery and incubated for 2 days. After 2 days of incubation, H\&E staining showed that the mesenchymal stem cells and ndMSCs adhered and spread well in the lumen and surface of the decellularized artery conduit (Figure 6). The seeded mesenchymal stem cells and ndMSCs did not become clump and form aggregation. The decellularized HUC artery conduit retained majority of extracellular matrix and support the cells seeded thus highlighted the good biocompatibility property.

The adherence of mesenchymal stem cells and ndMSCs on the vessels wall could be due to extracellular matrix collagen fibers that were preserved during decellularization. Extracellular matrix is an important

MC (MSCs seeded conduit)
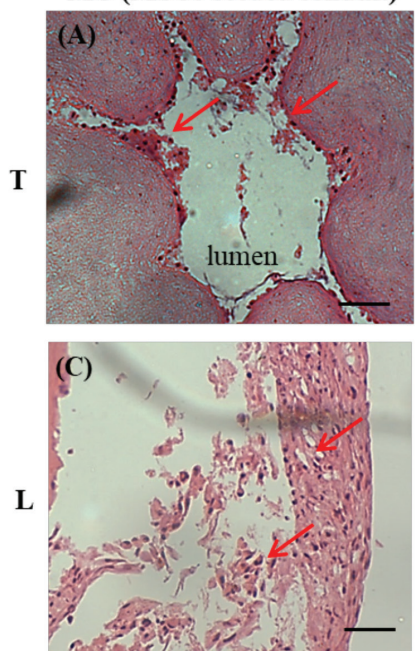

Magnification, $10 \times$ Scale bar, $100 \mu \mathrm{m}$

FIGURE 6. The cell attachment of MSCs seeded conduit (MC) (A, C) and ndMSCs seeded conduit (NC) (B,D) as observed by H\&E staining. $H \& E$ staining showed cells were present and adhered in the lumen and surface of the decellularized artery conduit. Arrows indicated presence of the cells. $\mathrm{T}=$ transverse section, $\mathrm{L}=$ longitudinal section
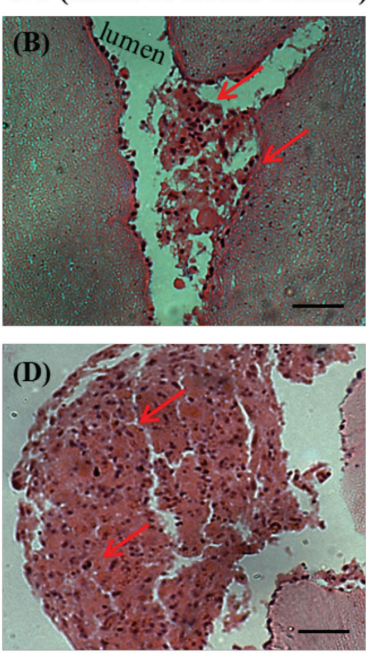

component for cell adhesion, migration, proliferation and adaptive tissue responses (Badylak et al. 2009). Besides, the collagen fibers of an extracellular matrix scaffold play a vital role in determining its biocompatibility and biomechanical properties. As opposed to previous studies that reported about the success of seeding neuronal cell line and human umbilical vein endothelial cells into the decellularized HUC artery for nerve regeneration (Crouzier et al. 2009; Gui et al. 2009), in this study, the decellularized HUC artery supported the seeding of the mesenchymal stem cells and neurodifferentiated mesenchymal stem cells.

\section{CONCLUSION}

In this study, nerve conduit using decellularized HUC artery seeded with neurodifferentiated human MSCs (ndMSCs) was successfully developed. This study showed the potential utility of neurodifferentiated MSCs using $C$. asiatica for critical size peripheral nerve injury. This technique offers a promising approach in the development of nerve conduit and as an alternative strategy to the treatment of critical nerve defect. However, preclinical study needs to be done to see its effectiveness before it can be applied in clinical trial.

\section{ACKNOWLEDGEMENTS}

This study was funded by the Ministry of Agriculture and Agro-based Industry Malaysia under NKEA Research Grant Scheme (NRGS) (Project code: NH 1014 D048) and Universiti Kebangsaan Malaysia (Project code: FF-2017175). The author would like to thank Prof Dr. Mohd Ilham Adenan from Atta-ur-Rahman Institute for Natural Product Discovery, Universiti Teknologi MARA, Malaysia, who kindly provided $C$. asiatica for use in the experiment.

\section{REFERENCES}

Badylak, S.F., Freytes, D.O. \& Gilbert, T.W. 2009. Extracellular matrix as a biological scaffold material: Structure and function. Acta Biomaterialia 5(1): 1-13.

Crouzier, T., McClendon, T., Tosun, Z. \& McFetridge, P.S. 2009. Inverted human umbilical arteries with tunable wall thicknesses for nerve regeneration. Journal of Biomedical Materials Research Part A 89A(3): 818-828.

Deal, N.D., Griffin, J.W. \& Hogan, M.V. 2012. Nerve conduits for nerve repair or reconstruction. JAAOS-Journal of the American Academy of Orthopaedic Surgeons 20(2): 63-68.

Deng, J., Petersen, B.E., Steindler, D.A., Jorgensen, M.L. \& Laywell, E.D. 2006. Mesenchymal stem cells spontaneously express neural proteins in culture and are neurogenic after transplantation. Stem Cells 24(4): 1054-1064.

Dominici, M., Le Blanc, K., Mueller, I., Slaper-Cortenbach, I., Marini, F., Krause, D., Deans, R., Keating, A., Prockop, D.J. \& Horwitz, E. 2006. Minimal criteria for defining multipotent mesenchymal stromal cells. The International Society for cellular therapy position statement. Cytotherapy 8(4): 315-317.

Gilpin, A. \& Yang, Y. 2017. Decellularization strategies for regenerative medicine: From processing techniques to 
applications. BioMed Research International 2017: Article ID. 9831534.

Gordon, T., Sulaiman, O. \& Boyd, J.G. 2003. Experimental strategies to promote functional recovery after peripheral nerve injuries. Journal of the Peripheral Nervous System 8(4): 236-250.

Gui, L., Muto, A., Chan, S.A., Breuer, C.K. \& Niklason, L.E. 2009. Development of decellularized human umbilical arteries as small-diameter vascular grafts. Tissue Engineering Part A 15(9): 2665-2676.

Hassan, N.H., Sulong, A.F., Ng, M..H., Htwe, O., Idrus, R.B.H., Roohi, S., Naicker, A.S. \& Abdullah, S. 2012. Neuraldifferentiated mesenchymal stem cells incorporated into muscle stuffed vein scaffold forms a stable living nerve conduit. Journal of Orthopaedic Research 30(10): 16741681 .

Hidayah, N.H., Fadzli, A., Ng, M.H., Ruszymah, B.H.I., Naicker, A.S. \& Shalimar, A. 2012. Porous PLGA sheet and acellularized muscle stuffed vein seeded with neuraldifferentiated MSCs are potential scaffolds for nerve regeneration. Regen. Res. 1: 1-7.

Höke, A. 2006. Mechanisms of disease: What factors limit the success of peripheral nerve regeneration in humans? Nature Reviews Neurology 2(8): 448-454.

Jadalannagari, S.\& Aljitawi, O.S. 2015. Ectodermal differentiation of Wharton's jelly mesenchymal stem cells for tissue engineering and regenerative medicine applications. Tissue Engineering Part B: Reviews 21(3): 314-322.

Jamil, S.S., Nizami, Q.\& Mehboobus, S. 2007. Centella asiatica (Linn.) Urban: A review. Natural Product Radiance 6(2): 158-170.

Jiang, H., Zheng, G., Junwei, L.V., Chen, H., Jinjin, L., Li, Y., Fan, G. \& Ding, X. 2016. Identification of Centella asiatica's effective ingredients for inducing the neuronal differentiation. Evid. Based Complement. Alternat. Med. 2016: Article ID. 9634750 .

Kaizawa, Y., Kakinoki, R., Ikeguchi, R., Ohta, S., Noguchi, T., Oda, H. \& Matsuda, S. 2016. Bridging a $30 \mathrm{~mm}$ defect in the canine ulnar nerve using vessel-containing conduits with implantation of bone marrow stromal cells. Microsurgery 36(4): 316-324.

Kaizawa, Y., Kakinoki, R., Ikeguchi, R., Ohta, S., Noguchi, T., Takeuchi, H., Oda, H., Yurie, H. \& Matsuda, S. 2017. A nerve conduit containing a vascular bundle and implanted with bone marrow stromal cells and decellularized allogenic nerve matrix. Cell Transplantation 26(2): 215-228.

Kehoe, S., Zhang, X. \& Boyd, D. 2012. FDA approved guidance conduits and wraps for peripheral nerve injury: A review of materials and efficacy. Injury 43(5): 553-572.

Liao, I.C., Wan, H., Qi, S., Cui, C., Patel, P., Sun, W. \& Xu, H. 2013. Preclinical evaluations of acellular biological conduits for peripheral nerve regeneration. Journal of Tissue Engineering 4: 2041731413481036.

Lim, J., Razi, Z.R.M., Law, J., Azmawati, Mohammed Nawi., Haji Idrus, Ruszymah. \& Ng. Min Hwei. 2016. MSCs can be differentially isolated from maternal, middle and fetal segments of the human umbilical cord. Cytotherapy 18(12): 1493-1502.

Liu, Z., Jin, Y.Q., Chen, L., Wang, Y., Yang, X., Cheng, J., Wu, W., Qi, Z.\& Shen, Z. 2015. Specific marker expression and cell state of Schwann cells during culture in vitro. PLoS One 10(4): e0123278.
Lokanathan, Y., Ng, M.H., Shariful Hasan, Anuar Ali, Mazzre Mahmod, Ohnmar Htwe, Sharifah Ahmad Roohi, Ruszymah, Bt Hj Idrus, Shalimar Abdullah \& Amaramalar Selvi Naicker 2014. Olfactory ensheathing cells seeded muscle-stuffed vein as nerve conduit for peripheral nerve repair: A nerve conduction study. Journal of Bioscience and Bioengineering 118(2): 231-234.

Lokanathan, Y., Omar, N., Ahmad Puzi, N.N., Saim, A. \& Hj Idrus, R. 2016. Recent updates in neuroprotective and neuroregenerative potential of Centella asiatica. Malays $J$. Med.Sci. 23(1): 4-14.

Mallis, P., Gontika, I., Poulogiannopoulos, T., Zoidakis, J., Vlahou, A., Michalopoulos, E., Chatzistamatiou, T., Papassavas, A.\& Stavropoulos-Giokasa, C. 2014. Evaluation of decellularization in umbilical cord artery. Transplantation Proceedings 46(9): 3232-3239.

Michetti, F., Corvino, V., Geloso, M.C., Lattanzi, W., Bernardini, C., Serpero, L. \& Gazzolo, D. 2012. The S100B protein in biological fluids: More than a lifelong biomarker of brain distress. Journal of Neurochemistry 120(5): 644-659.

Mohandas R.K., Muddanna, R.S.\& Rao, S.G. 2009. Enhancement of amygdaloid neuronal dendritic arborization by fresh leaf juice of Centella asiatica (Linn) during growth spurt period in rats. Evidence-Based Complementary and Alternative Medicine 6(2): 203-210.

Mohd Heikal, M., Siti Mariam, H., Mohd Ilham, A., Mee Fong, C., Aminuddin, B.S. \& Ruszymah, B.H.I. 2014. Antiproliferative activities of Centella asiatica extracts on human respiratory epithelial cells in vitro. Journal of Medicinal Plants Research 8(24): 864-869.

Neuhuber, B., Swanger, S.A., Howard, L., Mackay, A. \& Fischera, I. 2008. Effects of plating density and culture time on bone marrow stromal cell characteristics. Experimental Hematology 36(9): 1176-1185.

Noor, M.M. \& Ali, N.M. 2004. Kesan in vivo ekstrak daun Centella asiatica ke atas histologi testis dan kualiti sperma mencit. Sains Malaysiana 33(2): 97-103.

Norazzila, O., Yogeswaran, L. \& Ruszymah, B.H.I. 2017. Comparison of cytotoxicity measurements of Centella asiatica (L.) on human wharton's jelly-derived mesenchymal stem cells in vitro via $\mathrm{mtt}$ and prestoblue assay. Regenerative Research 5(2): 10-18.

Norazzila, O., Yogeswaran, L., Mohd Razi Zainul Rashid \& Ruszymah Idrus. 2018. The effects of Centella asiatica (L.) Urban on neural differentiation of human mesenchymal stem cells in vitro. Frontiers in Cellular Neuroscience doi: 10.3389/conf.fncel.2016.36.00183.

Nurlaily, A., Ar, N.B. \& Musalmah, M. 2012. Comparative antioxidant and anti-inflammatory activity of different extracts of Centella asiatica (L.) Urban and its active compounds, asiaticoside and madecassoside. Medicine and Health 7(2): 62-72.

Omar, N.S., Zakaria, Z.A.C., Mian Then Sue, Wan Ngah Wan Zurinah \& Musalmah Mazlan. 2011. Centella asiatica modulates neuron cell survival by altering caspase- 9 pathway. Journal of Medicinal Plants Research 5(11): 2201-2209.

Puttarak, P., Brantner, A. \& Panichayupakaranant, P. 2016. Biological activities and stability of a standardized pentacyclic triterpene enriched Centella asiatica extract. Natural Product Sciences 22(1): 20-24.

Quint, C., Kondo, Y., Manson, R.J., Lawson, J.H., Dardik, A. \& Niklason, L.E. 2011. Decellularized tissue-engineered blood vessel as an arterial conduit. Proceedings of the National Academy of Sciences 108(22): 9214-9219. 
Ray, W.Z. \& Mackinnon, S.E. 2010. Management of nerve gaps: Autografts, allografts, nerve transfers, and end-to-side neurorrhaphy. Experimental Neurology 223(1): 77.

Rodríguez-Rodríguez, V.E., Martínez-González, B., QuirogaGarza, A., Reyes-Hernández, C.G., de la Fuente-Villarreal, D., de la Garza-Castro, O., Guzmán-López, S. \& ElizondoOmaña, R.E. 2017. Human umbilical vessels: Choosing the optimal decellularization method. ASAIO Journal (American Society for Artificial Internal Organs: 1992) 64(5): 575-580.

Roy, S., Silacci, P. \& Stergiopulos, N. 2005. Biomechanical proprieties of decellularized porcine common carotid arteries. American Journal of Physiology-Heart and Circulatory Physiology 289(4): H1567-H1576.

Ruszymah, B.H.I., Chowdhury, S.R., Nur Azeanty Bt Abdul Manan, Ooi Sew Fong, Mohd Ilham Adenan \& Aminuddin Bin Saim. 2012. Aqueous extract of Centella asiatica promotes corneal epithelium wound healing in vitro. Journal of Ethnopharmacology 140(2): 333-338.

Safwani, W.K.Z.W., Makpol, S., Sathapan, S. \& Chua, H.K. 2012. The impact of long-term in vitro expansion on the senescenceassociated markers of human adipose-derived stem cells. Applied Biochemistry and Biotechnology 166(8): 2101-2113.

Said, M. 2009. Traditional Malaysian salads (ulam) as a source of antioxidants. Prosiding Seminar Kimia Bersama UKMITB. pp. 9-11.

Schaner, P.J., Martin, N.D., Tulenko, T.N., Shapiro, I.M., Tarola, N.A., Leichter, R.F., Carabasi, R.A. \& DiMuzio, P.J. 2004. Decellularized vein as a potential scaffold for vascular tissue engineering. Journal of Vascular Surgery 40(1): 146-153.

Shalaby, S.M., Amal, S., Ahmed, F.E., Shaban, S.F., Wahdan, R.A., Kandel, W.A. \& Mohammed, S.S. 2017. Combined Wharton's jelly derived mesenchymal stem cells and nerve guidance conduit: A potential promising therapy for peripheral nerve injuries. The International Journal of Biochemistry \& Cell Biology 86: 67-76.

Somboonwong, J., Kankaisre, M., Tantisira, B. \& Tantisira, M.H. 2012. Wound healing activities of different extracts of Centella asiatica in incision and burn wound models: An experimental animal study. BMC Complementary and Alternative Medicine 12(1): 103

Soumyanath, A., Zhong, Y.P., Gold, S.A., Yu, X., Koop, D.R., Bourdette, D. \& Gold, B.G. 2005. Centella asiatica accelerates nerve regeneration upon oral administration and contains multiple active fractions increasing neurite elongation in-vitro.J.Pharm. Pharmacol. 57(9): 1221-1229.

Sulong, A.F. \& Hassan, N.H. 2014. Collagen-coated polylacticglycolic acid (PLGA) seeded with neural-differentiated human mesenchymal stem cells as a potential nerve conduit. Adv. Clin. Exp. Med. 23: 353-362.

Sun, F., Zhou, K., Mi, W-J. \& Qiu, J-H. 2011. Combined use of decellularized allogeneic artery conduits with autologous transdifferentiated adipose-derived stem cells for facial nerve regeneration in rats. Biomaterials 32(32): 8118-8128.

Tiwari, S., Gehlot, S. \& Gambhir, I.S. 2011. Centella asiatica: A concise drug review with probable clinical uses. Journal of Stress Physiology \& Biochemistry 7(1): 38-44.
Tuan-Mu, H.Y., Yu, C.H. \& Hu, J.J. 2014. On the decellularization of fresh or frozen human umbilical arteries: Implications for small-diameter tissue engineered vascular grafts. Annals of Biomedical Engineering 42(6): 1305-1318.

Wakao, S., Matsuse, D. \& Dezawa, M. 2014. Mesenchymal stem cells as a source of Schwann cells: Their anticipated use in peripheral nerve regeneration. Cells Tissues Organs 200(1): 31-41.

Wanakhachornkrai, O., Pongrakhananon, V., Chunhacha, P., Wanasuntronwong, A., Vattanajun, A., Tantisira, B., Chanvorachote, P. \& Tantisira, M.H. 2013. Neuritogenic effect of standardized extract of Centella asiatica ECa233 on human neuroblastoma cells. BMC Complement. Altern. Med. 13: 204

Xu, Y., Zhang, Z., Chen, X., Li, R., Li, D. \& Feng, S. 2016. A silk fibroin/collagen nerve scaffold seeded with a co-culture of schwann cells and adipose-derived stem cells for sciatic nerve regeneration. PloS One 11(1): e0147184.

Zhan, X., Gao, M., Jiang, Y., Zhang, W.W., Wong, W.M., Yuan, Q., Su, H., Kang, X., Dai, X., Zhang, W., Guo, J. \& Wu, W. 2013. Nanofiber scaffolds facilitate functional regeneration of peripheral nerve injury. Nanomedicine: Nanotechnology, Biology and Medicine 9(3): 305-315.

Zhuang, Y., Li, D., Fu, J., Shi, Q., Lu, Y. \& Ju, X. 2015. Comparison of biological properties of umbilical cordderived mesenchymal stem cells from early and late passages: Immunomodulatory ability is enhanced in aged cells. Molecular Medicine Reports 11(1): 166-174.

Hanita Mohd Hussin, Ruszymah Haji Idrus \&

Yogeswaran Lokanathan*

Tissue Engineering Centre

UKM Medical Centre

Universiti Kebangsaan Malaysia

Jalan Yaacob Latif, Bandar Tun Razak

56000 Cheras, Kuala Lumpur, Federal Territory

Malaysia

Ruszymah Haji Idrus

Department of Physiology

UKM Medical Centre

Universiti Kebangsaan Malaysia

Jalan Yaacob Latif, Bandar Tun Razak

56000 Cheras, Kuala Lumpur, Federal Territory

Malaysia

*Corresponding author; email: lyoges@ppukm.ukm.edu.my

Received: 29 March 2018

Accepted: 6 July 2018 